\title{
The Need of Social Reorganization in America
}

\author{
By Oswald Garrison Villard
}

Editor of The Nation

WHEN one has just beheld on the other side of the ocean elemental human forces unleashed; the very deeps of society breaking up; the pillars of civilization rocking on their bases; whole classes of the citizenship of nations lunging forward to take upon themselves the burdens of governing; when one has gazed upon a spectacle the like of which no other generation has beheld in more than a century, one comes back humble, indeed, and more than ever convinced of the fallibility of any single human judgment.

How can anybody just from Germany, France and England who has looked beneath the surface undertake to discourse upon the "organization of peace"? When I arrived in Paris from Berlin, an American statesman asked me, "How can I, Mr. Villard, think of the League of Nations, when civilization is all but collapsing before our eyes and may yet go down?" I not only agreed with him; I found he agreed with me that the war which was to make the world safe for democracy had thus far only made the world less safe for democracy than it had been since democracies were attempted.

But the darkness of the skies abroad, of which people in America are so amazingly unaware, is no reason for failing to take note of the portents and to make every possible effort to ward off the storm. Here at home reorganization $i s$ the great need of the hour. All the more so if one believes as I do that the terrible unrest abroad and the steady drift towards communism will inevitably make itself felt here if prompt steps are not taken to allay the prevailing discontent. It has been the fashion in certain quarters to dilate upon the wonderful effect of the war in making the whole nation one. This is a delusion. Never were the workers as unhappy. Never were there larger classes of our citizenship filled with bitterness and a feeling of being wronged. May Day has borne testimony to that. It is very easy to say when one hears that four millions of foreign born Americans are planning 
to return to Europe that it is "good riddance of bad rubbish." But aside from the economic loss of these people, there is nearly a tenth of our citizenship-down-trodden, ill-treated, disfranchised and disadvantaged - that cannot emigrate even though it would and these are beginning to seethe with unrest and anger. I refer, of course, to the colored people, now estimated at ten millions, deemed good enough to fight for democracy, but not good enough to experience it or to live as part of one. Meek, patient and long suffering, these Americans are among the first who should be thought of in any plan of organization for peace. If we continue to drift without a program for the advancement of these people to real democracy, we may be sure that they will espouse socialism, or communism, or bolshevism, or anything else which will promise them the equality they are denied.

But my plea is not especially for them or any other class today. I heard Secretary Daniels remark truly in Paris that a hundred years had elapsed since August 1, 1914, and I took the liberty of amending this by saying that a hundred years had passed since the armistice. There are pressing such new and difficult problems abroad that the first step toward organization for peace in this country ought to be the creation of an absolutely unbiased, really representative society or bureau to study what is happening abroad and to report thereon in some way to compel the attention of the public, the newspapers and the Congress to what is going on. Let us take this new-old device of the soviet form of government. To suggest that it may perhaps have merit is to subject oneself to the charge of being a bolshevist-a word which has just taken the place of "pro-German" as an epithet in our national vocabulary. Yet the other day one of our own American officials at Paris solemnly assured the newspaper men that if the soviet type of government were made really representative he saw no reason why it should not be as democratic as any government, if not more so. It was only to the men who were running the present unfair and undemocratic soviet government in Russia that our government objected, he declared.

Obviously, if this is the case it is time for people everywhere in America to take the soviet seriously and to investigate it dispassionately. Personally I feel sure that the soviet has come to stay in Europe until it has been thoroughly tried out. While I 
was in Germany all political parties agreed that the new German constitution now being drafted in Weimar shall contain within it the soviet as the unit of local self-government and that it shall stop short only of the respective parliaments of the several states and of the federal state. I heard everywhere the belief that this soviet procedure would be the best device for the reorganization of industry. Everyone admitted that that extraordinary demobilization of the German army-when it came back beaten, hungry, bitter at its officers and convinced that it had been lied to and tricked - could not have been put through without bloodshed or disorder of any kind if it had not been done by the soldiers' and workmen's councils which were everywhere formed. I met in Berlin the active head of the German Anti-Bolshevist Society, Dr. Stadler, and found him a firm believer in the permanence of the soviet in industry and local government, although he is fighting bolshevism day and night. Dr. Stadler, like everyone else whom I met in Paris, London, Berlin and Bern, agreed that Lenin was quite the ablest statesman in Europe today.

Now, plainly if this German, who saw the forming of Lenin's government when a prisoner in Russia, and a leading American official in Paris express opinions like these it is time for Americans to look into the soviet in a scientific spirit. It would certainly not do for us to let the wicked Germans get the advantage of us by picking up something good in government and getting the jump on the rest of the world. Perhaps we can let them go ahead and be our experiment station and discover whether there is anything worth while in it or not. But meanwhile we must surely have some body or group watching the experiment and passing upon it and warning us in time if we are losing a good thing.

There is something attractive in group representation, which is what the soviet is. I was once in a modest way a college teacher and I cannot say that the idea of college professors as a group having a voice in government is altogether unattractive. I have a feeling, moreover, that our great capitalists might like a governmental device by which their representatives could sit in governmental bodies with the right to be heard open and above board without recourse either to boodle funds or paid lobbyists or underhand means of protecting their rights. Please do not misunderstand. I am not convinced that we have anything what- 
ever to gain from the soviet. I am only a journalist who is trying to be open-minded about it and to record the facts of its progress or decay, but I am almost ashamed to admit that $I$ am a journalist, because there has been so much lying in the press about Russia and everything that has gone on there.

It is not only as to Russia that we need information. There is revolution going on in England today, peaceable revolution, thank fortune, carried on in the good old Anglo-Saxon way without bloodshed; yet still revolution. I found no Englishman in Paris who would deny that it was revolution, or assert that it was not going any further. Indeed, in the English Labor Party's program, in the recent decision in the case of the coal miners, in the almost certain nationalization of the mines, in all these we find clear indications of the tremendous change coming over the industrial life of England. Change which will be hastened and not delayed by the distressing financial situation in which she finds herself, and out of which she can hardly extricate herself without severest sacrifices unless she deliberately adopts a policy of disarmament and ceases to maintain a large navy and large armies to rule over her dependent peoples by force. Whatever policies she adopts, she is going to be leading the world in so many ways in her social changes that America must be following her with profoundest interest and care. It hurts our feelings to hear people say abroad that we are at least forty years behind the times in America. But this they are saying, and since our daily press cannot be relied upon to give us complete and accurate news of what is happening, we must find other ways of reorganizing for peace by following events abroad with zealous care.

This is all the more necessary if what has been said so often during this war is true-that we have abandoned our isolation and are now to be a part, through an alliance with France and our partnership in the League of Nations, of all the happenings abroad; that, absolutely forgetting the advice of Washington, we are to have entangling alliances. We have recently seen how embarrassing it is to be in a war without knowing about the secret agreements of our allies. Plainly, if we are to play the old diplomatic game, we should not do it blindfolded. Let us find a way to get all the light we can.

But most essential of all, if we are going to organize for peace 
on any sound basis, is the need for a liberal and a tolerant spirit in dealing with the problems before us and with those of our fellow-citizens who are so unkind as to have other views than ours as to how our America and the world should be reorganized. It is not surprising that war-worn Europe should be in the frame of mind in which it is now the custom to throw a hand-grenade at the fellow one does not like. But we have escaped the real stress and strain of war so that it is rather trying to read of the recent May Day happenings throughout the country. We must surely all unite to preach the doctrine that it is utterly wrong to try to upset or alter this government by force, however inconsistent this may seem with our recent actions. It is a mighty poor American and a stupid, dull reformer who lets himself believe that the way to get a better country is to organize it by bullets or the cowardly infernal machine. That way lies madness, as Bavaria has just shown.

But if we try to suppress with rigid hand those who would urge a different form of society; if self-constituted mobs of uniformed men are to become censors of what the dissatisfied may or may not say; if we deny the right of free speech, and free thought to the dissenters; then we are padlocking the safety valve. If we are going to meet them with bitterness and anger, with threats of deportation and prison, then shall we merely intensify the nation-wide unrest which the war has done so much to increase. To let loose an idea upon the world is often a terrible thing, but still more terrible is the effort to combat ideas by force and by incarceration. The only way that we can organize for peace is by setting ourselves rigidly to inquiring what is wrong with us and what we can do to better the situation. Let us have a national commission of inquiry-not of political back-numbers and lawyers and elder statesmen and still elder labor leadersbut let us have upon it the spirit of youth and progress, with even a non-partisan leaguer and a socialist or two. They usually do not bite when in private company and though they have not converted many of us Americans to their views they sometimes have interesting and useful ideas to impart.

When the red flag waves over the public buildings of two-thirds of Europe; when there are twenty-two straight-out socialist republics being organized in Germany alone, it is surely time to examine 
into this strange doctrine which numbers its followers by the hundred millions between Siberia and Paris. Americans ought surely not to disregard the fact that the conservatives in Germany and Russia today are now the majority socialists who at the outbreak of the war were the extreme radicals. We must likewise not overlook the truth that our two great political parties are today the most conservative parties in the western world, and that they are even further to the right than the professed British Tories. 'There is, therefore, no political alternative for those whose desires are unexpressed than to go to the Socialists. If we undertake to organize wisely for peace we shall lend all possible aid to a liberal party which shall take middle ground, else shall we see the cleft and the bitter feeling of the hour grow. In England the Labor Party points the way. Perhaps our own new-born Labor Party, if it does not confine itself merely to those who hold union cards, can supply the crying need.

Whether it does or does not, one thing is certain, the movement to the left in America is coming. No one can study conditions abroad and rest assured that America can remain apart from the imponderable world currents and keep unchanged the old America so many of us liked so well, loved so profoundly. Shall we guide it and direct it into wise channels by ascertaining and removing the causes of social and economic discontent, or shall we combat it by force and repression and lynching-and thereby compel it to nihilism and to what people consider bolshevism? That is the fundamental question to be answered before there can be any wise organizing for peace. 